\title{
Safety of Lactobacillus plantarum ST8Sh and Its Bacteriocin
}

\author{
Svetoslav Dimitrov Todorov ${ }^{1} \cdot$ Luana M. Perin $^{1} \cdot$ Bruno M. Carneiro $^{2,3} \cdot$ Paula Rahal $^{2}$ • \\ Wilhelm Holzapfel $^{4} \cdot$ Luís Augusto Nero $^{1}$
}

Published online: 23 February 2017

(C) Springer Science+Business Media New York 2017

\begin{abstract}
Total DNA extracted from $L b$. plantarum ST8Sh was screened for the presence of more than 50 genes related to production of biogenic amines (histidine decarboxylase, tyrosine decarboxylase, and ornithine decarboxylase), virulence factors (sex pheromones, gelatinase, cytolysin, hyaluronidase, aggregation substance, enterococcal surface protein, endocarditis antigen, adhesion of collagen, integration factors), and antibiotic resistance (vancomycin, tetracycline, erythromycin, gentamicin, chloramphenicol, bacitracin). $L b$. plantarum ST8Sh showed a low presence of virulence genes. Only 13 genes were detected (related to sex pheromones, aggregation substance, adhesion of collagen, tetracycline, gentamicin, chloramphenicol, erythromycin, but not to vancomycin, and bacitracin) and may be considered as indication of safety for application in fermented food products. In addition, interaction between $L b$. plantarum ST8Sh and drugs from different groups were determined in order to establish possible application of the strain in combination with commercial drugs. Cytotoxicity of the semi-purified bacteriocins produced by $L b$. plantarum ST8Sh was depended on applied concentration-highly cytotoxic when applied at $25 \mu \mathrm{g} / \mathrm{mL}$ and no cytotoxicity at $5 \mu \mathrm{g} / \mathrm{mL}$.
\end{abstract}

Svetoslav Dimitrov Todorov

slavi310570@abv.bg

1 Veterinary Department, Universidade Federal de Viçosa, Campus UFV, Viçosa, Minas Gerais 36570-900, Brazil

2 Departamento de Engenharia e Tecnologia de Alimentos, UNESP Universidade Estadual Paulista, Instituto de Biociências, Letras e Ciências Exatas, São José do Rio Preto, SP, Brazil

3 Instituto de Ciências Exatas e Naturais, Universidade Federal de Mato Grosso, Rondonópolis, MT, Brazil

4 GEE, Handong Global University, Pohang, South Korea
Keywords Lactobacillus plantarum • Probiotics · Bacteriocins $\cdot$ Safety $\cdot$ Virulence $\cdot$ Cytotoxicity

\section{Introduction}

Research on lactic acid bacteria (LAB) with probiotic potential is focused on different areas, including re-establishing of the gastrointestinal (GIT) microbiota, prevention and treatment of GIT disorders, stimulation of the immune system, treatment of skin diseases, prevention of some types of cancer, treatment of Helicobacter pylori, and involvement in oral health [1]. Parallel to a high number of reports dedicated to the study of beneficial properties of probiotic LAB, a limited number of studies focus on the safety aspects of these strains. Several Lactobacillus spp. have been granted GRAS status and are considered as safe for human and other animal applications. Different Lactobacillus spp. are associated with the traditional production of different fermented food products from plant, meat, and dairy origin. However, some clinical cases were described and linked to some strains of Lactobacillus spp. typical of various fermented foods [2-4].

With the better understanding of the microbial interactions, including horizontal gene transfer and the genetic basis of potential virulence, it is necessary to re-evaluate the perspective related to the safety issues of Lactobacillus spp. From traditional point of application, some strains can be considered as safe to be used as starter and beneficial cultures; however, they need to be carefully examined for the potential presence of virulence factors, and to take into account that most probably these strains will be present in high viable cell numbers when applied as probiotics/beneficial cultures. Considering all this, safety aspects of the probiotic LAB need to be carefully examined on a strain by strain basis, and the risk of delivering virulence factors to the host should be excluded. 
It is important to check for antibiotic resistance, as probiotic $L A B$ can act as potential reservoirs of (transferable) resistance genes that can result in multidrug resistant strains [5]. Probiotics are frequently prescribed to the consumers under treatment for a variety of illnesses as an accompanying therapy. However, the beneficial effects of the probiotic strain may be reduced by possible interactions with the medication used by these patients/consumers. An important issue is that the interaction between medications or antibiotics and probiotic bacteria in the GIT depends on their concentration in this environment $[6,7]$. In this regard, determination of Minimal Inhibitory Concentration (MIC) values in the interaction between probiotic $\mathrm{LAB}$ and drugs is an essential aspect in the evaluation of their efficacy. Special attention needs to be given to drugs for treatment of chronic diseases, since, due to their long-term application, they may accumulate in the GIT and affect the viability of probiotic LAB [8].

Production of antimicrobial peptides (bacteriocins) may be a complimentary characteristic for probiotic LAB. Bacteriocins can be involved in the reduction of pathogenic bacteria from the GIT provided these pathogens are sensitive to the produced bacteriocins. Some authors are even suggesting application of bacteriocins in the treatment of some pathogens, including multidrug resistant Staphylococcus aureus, Mycobacterium spp., and some viral and fungal infections in parallel to applied antibiotics [9]. However, potential cytotoxicity of the bacteriocins may constitute a safety risk and needs more attention. Toxicological studies have showed that nisin intake does not cause toxic effects to the human body with an estimated lethal dose (LD50) of $6950 \mathrm{mg} / \mathrm{kg}$, which is similar to that of salt, when administered orally [10]. In general, some authors have associated LD50 of bacteriocins with digestive enzymes capable of rapidly inactivating these substances such as trypsin and chymotrypsin produced in the pancreas [11-13]. However, different bacteriocins can have a high variation in the molecular mass and amino acid sequence, including even the presence of some non-protein subunits involved in their activity [14]; these features may interfere with their cytotoxicity. Thus, the safety evaluation of each new bacteriocin, both as candidate for a medical or biopreservation application needs to be performed.

In this work, we explore safety aspects of $L b$. plantarum ST8Sh, a strain isolated from fermented Bulgarian salami "Shpek" $[15,16]$ related to the presence of genes related to virulence, antibiotic resistance and production of biogenic amines, physiological tests related to expression of some virulence factors, partial purification of expressed bacteriocin/s and determination of its/their cytotoxicity, and inhibitory interactions between $\mathrm{Lb}$. plantarum ST8Sh and some selected commercial drugs.

\section{Material and Methods}

\section{Strains and Media}

Lb. plantarum ST8Sh, a bacteriocinogenic strain isolated from Bulgarian salami "Shpek" [15] and Listeria monocytogenes ATCC 7644, L. monocytogens ScottA, Enterococcus faecalis ATCC 19443, and Lb. sakei ATCC 15521 as test microorganisms, were cultured in MRS broth and BHI broth (Difco, Detroit, MI, USA), respectively, incubated at $30^{\circ} \mathrm{C}$ and stored at $-80{ }^{\circ} \mathrm{C}$, in the presence of $20 \%$ glycerol.

\section{Bacteriocin Production and Partial Purification}

Lb. plantarum ST8Sh was cultured in MRS broth at $37^{\circ} \mathrm{C}$ for $24 \mathrm{~h}$. Cell-free supernatant was obtained after centrifugation at $5000 \mathrm{~g}$ for $10 \mathrm{~min}$ at $4{ }^{\circ} \mathrm{C}$; $\mathrm{pH}$ was corrected to $6.0-6.5$ with $1 \mathrm{M} \mathrm{NaOH}$ and treated for $10 \mathrm{~min}$ at $80{ }^{\circ} \mathrm{C}$. Bacteriocin was precipitated by addition of ammonium sulfate to the cell-free supernatant to obtain $60 \%$ saturation and stirred for $4 \mathrm{~h}$ at $4{ }^{\circ} \mathrm{C}$. After centrifugation for $1 \mathrm{~h}$ at $12000 \mathrm{~g}$ at $4{ }^{\circ} \mathrm{C}$, the resulting pellet was re-suspended in $100 \mathrm{~mL}$ of $25 \mathrm{mM}$ phosphate buffer $\left(\mathrm{pH}\right.$ 6.5), and loaded on SepPak $\mathrm{C}_{18}$ cartridge (Waters, Millipore, MA, USA), and bacteriocin eluted with 60 and $80 \%$ iso-propanol in $25 \mathrm{mM}$ phosphate buffer ( $\mathrm{pH}$ 6.5). The active fraction was dried under vacuum (Speed-Vac, Savant, France), and the bacteriocin fraction was re-suspended in sterile distilled water and filtered using $0.22-\mu \mathrm{m}$ pore size filter units (Waters).

\section{Bacteriocin Test}

Titer of the expressed bacteriocin was determined as described by Todorov et al. [15]. The cell free supernatant or semipurified bacteriocin was serially $2 \times$ diluted in $100 \mathrm{mM}$ phosphate buffer $\mathrm{pH} 6.5$, and $10 \mu \mathrm{L}$ from each dilution has been spotted on the surface of BHI supplemented with $0.7 \%$ agar plated with $10^{5} \mathrm{CFU} / \mathrm{mL}$ of L. monocytogenes ATCC 7644, L. monocytogens ScottA, E. faecalis ATCC 19443, or Lb. sakei ATCC 15521 (final concentration). The highest dilution presenting an inhibition zone larger than $2 \mathrm{~mm}$ was considered as basis for calculation of Arbitrary Units per $\mathrm{mL}(\mathrm{AU} / \mathrm{ml})$ taking in consideration the volume of the deposited material and dilution factor.

\section{Cytotoxicity of the Expressed Bacteriocins/s}

Human hepatocellular carcinoma cell line (Huh7.5) $\left(5 \times 10^{3}\right.$ cells/well $)$ were seeded into a 96 -well plate and incubated for $24 \mathrm{~h}$ prior to treatment with semi-purified bacteriocin produced by $L b$. plantarum ST8Sh. Then the supernatants were removed and substituted by $100 \mu \mathrm{L}$ of DMEM (Dulbecco's Modified Eagle Medium, 
TermoFisher Scientific) supplemented with two different concentrations of semi-purified bacteriocin ST8Sh. After $48 \mathrm{~h}$, culture media was removed and a solution of 3-(4,5dimethylthiazol-2-yl)-2,5-diphenyltetrazolium bromide (MTT; $100.0 \mu \mathrm{L}$ ) was added to each well containing the samples. Plate was incubated for $30 \mathrm{~min}$ at $37^{\circ} \mathrm{C}$, and MTT crystals were solubilized with $100 \mu \mathrm{L}$ of DMSO (Dimethyl sulfoxide, Sigma), and light absorbance was measured at $570 \mathrm{~nm}$. Cytotoxicity values are a percentage of the absorbance of the treated sample compared to the control (media without bacteriocin).

\section{Detection of Virulence Genes}

Total DNA from $L b$. plantarum ST8Sh was isolated using the ZR Fungal/Bacterial DNA Kit (Zymo Research, Irvine, CA, USA) following the instructions of the manufacturer. All PCR reactions were performed using the GeneAmp ${ }^{\circledR}$ PCR Instrument System 9700 (Applied Biosystems, Foster City, USA). Lb. plantarum ST8Sh was tested for virulence genes gelE (gelatinase), hyl (hyaluronidase), asa 1 (aggregation substance), esp. (enterococcal surface protein), cylA (cytolisin), $e f a \mathrm{~A}$ (endocarditis antigen), ace (adhesion of collagen), van $\mathrm{A}$, $\operatorname{van} \mathrm{B}, \operatorname{van} \mathrm{C} 1, \operatorname{van} \mathrm{C} 2, \operatorname{van} \mathrm{C} 2 / \mathrm{C} 3$ (related to vancomycin resistance), erm $\mathrm{A}$, erm $\mathrm{B}$, erm $\mathrm{C}$ (related to erythromycin resistance), tet $\mathrm{K}$, tet $\mathrm{L}$, tet $\mathrm{M}$, tet $\mathrm{O}$, tet $\mathrm{S}$ (related to tetracycline resistance), $\operatorname{aac}\left(6^{\prime}\right)$-Ie- $a p h\left(2^{\prime \prime}\right)$-Ia (related gentamycin resistance), $\operatorname{aph}\left(3^{\prime}\right)$-IIIa, $\operatorname{ant}\left(4^{\prime}\right)$-Ia, $\operatorname{aph}\left(2^{\prime \prime}\right)$-Id, $\operatorname{aph}\left(2^{\prime \prime}\right)$-Ic, $\operatorname{aph}\left(2^{\prime \prime}\right)-\mathrm{Ib}$, ant(6)-Ia (related to aminoglycosides type antibiotics resistance), cat $\mathrm{A}$ (chloraphenicol resistance), bcrB, $b c r \mathrm{D}, b c r \mathrm{R}$ (related to bacitracin resistance), $c c f, c o b, c p d$ (related to sex pheromones), sprE (serine protease), int, int $\mathrm{Tn}$ (transposom related) and genes for amino acid decarboxylases: $h d c 1$ and $h d c 2$ (both related to histidine decarboxylase), $t d c$ (tyrosine decarboxylase), and $o d c$ (ornithine decarboxylase), using PCR protocols of Moraes et al. [17] and Fortuna et al. [18]. Primers used for assessment of the presence of virulence genes are presented in Table 1.

\section{Virulence Factors-Phenotypical Tests}

A culture of $L b$. plantarum ST8Sh was subjected to phenotypic tests to identify its virulence activity, according Barbosa et al. [19]. All tests were performed with different time and incubation temperature combinations in order to verify the production of the virulence factors in diverse conditions, detailed in the following, in three independent trials.

Gelatinase production was verified by spotting $1 \mu \mathrm{L}$ aliquots of the $24 \mathrm{~h}$ culture onto the surface of Luria Bertani agar (LB; Becton, Dickinson and Company BD, Franklin Lakes, NJ, USA) supplemented with 3\% $(w / v)$ gelatin $(\mathrm{BD})$ and incubated at 37 and $42{ }^{\circ} \mathrm{C}$ for $48 \mathrm{~h}$, at $25^{\circ} \mathrm{C}$ for $72 \mathrm{~h}$, and at 10 and $15^{\circ} \mathrm{C}$ for 10 days.
After incubation, the plates were maintained at $4{ }^{\circ} \mathrm{C}$ for $4 \mathrm{~h}$, and the hydrolysis of gelatin was recorded by the formation of opaque halos around the colonies [20].

Hemolytic activity was assessed by streaking the cultures onto trypticase soy agar (Oxoid) supplemented with defibrinated horse blood at $5 \%(\mathrm{v} / \mathrm{v})$ and incubated at 37 and $42{ }^{\circ} \mathrm{C}$ for $24 \mathrm{~h}, 25^{\circ} \mathrm{C}$ for $48 \mathrm{~h}$, and 10 and $15{ }^{\circ} \mathrm{C}$ for 10 days. The hemolysis formed by each isolate was classified as total or $\beta$-hemolysis (clear halos around the colonies), partial or $\alpha$ hemolysis (greenish halos around the colonies), and absent or $\gamma$-hemolysis [21].

Lipase production was assessed by spotting $1 \mu \mathrm{L}$ of cultures onto LB plates (BD) supplemented with $\mathrm{CaCl}_{2}$ (SigmaAldrich, at $0.2 \%, w / v$ ) and Tween 80 (Sigma-Aldrich, at $1 \%$, $v / \mathrm{v}$ ) and incubated at 37 and $42{ }^{\circ} \mathrm{C}$ for $48 \mathrm{~h}, 25{ }^{\circ} \mathrm{C}$ for $72 \mathrm{~h}$, and 10 and $15{ }^{\circ} \mathrm{C}$ for 10 days. The formation of clear halos around the colonies was recorded as lipase production [22].

DNAse was identified by spotting $1 \mu \mathrm{L}$ aliquots of the cultures onto the surface of DNAse methyl green agar (BD), and incubated at 37 and $42{ }^{\circ} \mathrm{C}$ for $48 \mathrm{~h}, 25^{\circ} \mathrm{C}$ for $72 \mathrm{~h}$, and 10 and $15{ }^{\circ} \mathrm{C}$ for 10 days. Positive results were identified by the formation of clear halos around the colonies [23].

\section{Effect of Commercial Drugs and Antibiotics}

Lb. plantarum ST8Sh was tested for resistance to drugs, according to de Carvalho et al. [8]. Thirty-three different commercial drugs were purchased in local drugstores (Sao Paulo, Brazil and Belogradtchik, Bulgaria) and solubilized in $5 \mathrm{~mL}$ of sterile water to achieve the concentrations indicated in Table 2. Overnight culture of $L b$. plantarum ST8Sh (MRS broth, $37{ }^{\circ} \mathrm{C}, 18 \mathrm{~h}$ ) was mixed into MRS soft agar $(1.0 \%, \mathrm{w} / \mathrm{v}$; Difco) in order to achieve the population of $10^{6} \mathrm{CFU} / \mathrm{mL}$. After solidification of the agar, each drug $(10 \mu \mathrm{L})$ was spotted onto the surface of the plates and incubated at $37{ }^{\circ} \mathrm{C}$ for $24 \mathrm{~h}$. The plates were examined for the presence of inhibition zones around the spotted medication, and the inhibition zones larger than $2 \mathrm{~mm}$ diameter were subjected to the determination of the minimal inhibition concentration (MIC). Serial twofold dilutions of the drugs were prepared in sterile water, and $10 \mu \mathrm{L}$ were spotted onto the surface of MRS soft agar plates, previously inoculated with $L b$. plantarum ST8Sh as described before. The plates were incubated at $37{ }^{\circ} \mathrm{C}$ for $24 \mathrm{~h}$ and examined for the presence of inhibition zones around the spots. The MIC was calculated, based on the highest dilution that resulted in inhibition halos of at least $2 \mathrm{~mm}$ diameter.

In a similar experimental approach, susceptibility of $L b$. plantarum ST8Sh to antibiotics (Table 3) was tested by the disk diffusion test, using discs from Oxoid (Hampshire, England). The inhibitory effect of the antibiotics was expressed in millimeters of the inhibition zones [8]. 
Table 1 Primer sequences utilized in the investigation of the presence/absence for virulence factors, antibiotic resistance, and biogenic amine production
Presence of virulence factor gene on genome of $L b$. plantarum ST8Sh

\begin{tabular}{|c|c|c|}
\hline $\begin{array}{l}\text { Virulence genes } \\
\text { gelE }\end{array}$ & - & TATGACAATGCTTTTTGGGAT \\
\hline hyl & - & $\begin{array}{l}\text { AGATGCACCCGAAATAATATA } \\
\text { ACAGAAGAGCTGCAGGAAATG }\end{array}$ \\
\hline asa 1 & + & $\begin{array}{l}\text { GACTGACGTCCAAGTTTCCAA } \\
\text { GCACGCTATTACGAACTATGA }\end{array}$ \\
\hline esp & - & $\begin{array}{l}\text { TAAGAAAGAACATCACCACGA } \\
\text { AGATTTCATCTTTGATTCTTG }\end{array}$ \\
\hline cylA & - & $\begin{array}{l}\text { AATTGATTCTTTAGCATCTGG } \\
\text { ACTCGGGGATTGATAGGC }\end{array}$ \\
\hline efaA & - & $\begin{array}{l}\text { GCTGCTAAAGCTGCGCTT } \\
\text { GCCAATTGGGACAGACCCTC }\end{array}$ \\
\hline ace & + & $\begin{array}{l}\text { CGCCTTCTGTTCCTTCTTTGGC } \\
\text { GAATTGAGCAAAAGTTCAATCG }\end{array}$ \\
\hline $\operatorname{erm} \mathrm{A}$ & - & $\begin{array}{l}\text { GTCTGTCTTTTCACTTGTTTC } \\
\text { TCTAAAAAGCATGTAAAAGAA }\end{array}$ \\
\hline erm $\mathrm{B}$ & + & $\begin{array}{l}\text { CTTCGATAGTTTATTAATATTAG } \\
\text { GAAAAGTACTCAACCAAATA AGTAACGG } \\
\text { TACTTAAATTGTTTA } \\
\text { TCAAAACATAATATAGATAAA }\end{array}$ \\
\hline tet $\mathrm{K}$ & + & $\begin{array}{l}\text { GCAAATATTGTTTAAATCGTCAAT } \\
\text { TTAGGTGAAGGGTTAGGTCC }\end{array}$ \\
\hline tet $\mathrm{L}$ & - & $\begin{array}{l}\text { GCAAACTCATTCCAGAAGCA } \\
\text { CATTTGGTCTTATTGGATCG }\end{array}$ \\
\hline tet $\mathrm{M}$ & - & $\begin{array}{l}\text { ATTACACTTCCGATTTCGG } \\
\text { GTTAAATAGTGTTCTTGGAG }\end{array}$ \\
\hline tet $\mathrm{O}$ & + & $\begin{array}{l}\text { CTAAGATATGGCTCTAACAA } \\
\text { GATGGCATACAGGCACAGAC }\end{array}$ \\
\hline tet $\mathrm{S}$ & - & $\begin{array}{l}\text { CAATATCACCAGAGCAGGCT } \\
\text { TCGGTATCTTAGCACATGTTG }\end{array}$ \\
\hline aac $\left(6^{\prime}\right)$-Ie-aph(2")-Ia & + & $\begin{array}{l}\text { TATYCKAYTATTTGGACGACG } \\
\text { CCAAGAGCAATAAGGGCATA }\end{array}$ \\
\hline $\operatorname{aph}\left(3^{\prime}\right)-$ IIIa & - & $\begin{array}{l}\text { CACTATCATAACCACTACCG } \\
\text { GCCGATGTGGATTGCGAAAA }\end{array}$ \\
\hline $\operatorname{ant}\left(4^{\prime}\right)-\mathrm{Ia}$ & - & $\begin{array}{l}\text { GCTTGATCCCCAGTAAGTCA } \\
\text { CAAACTGCTAAATCGGTAGAAGCC }\end{array}$ \\
\hline $\operatorname{aph}\left(2^{\prime \prime}\right)-\mathrm{Id}$ & - & $\begin{array}{l}\text { GGAAAGTTGACCAGACATTACGAACT } \\
\text { GTGGTTTTTACAGGAATGCCATC }\end{array}$ \\
\hline $\operatorname{aph}\left(2^{\prime \prime}\right)-\mathrm{Ic}$ & - & $\begin{array}{l}\text { CCCTCTTCATACCAATCCATATAACC } \\
\text { CCACAATGATAATGACTCAGTTCCC }\end{array}$ \\
\hline $\operatorname{aph}\left(2^{\prime \prime}\right)-\mathrm{Ib}$ & + & $\begin{array}{l}\text { CCACAGCTTCCGATAGCAAGAG } \\
\text { CTTGGACGCTGAGATATATGAGCAC }\end{array}$ \\
\hline ant (6)-Ia & - & $\begin{array}{l}\text { GTTTGTAGCAATTCAGAAACACCCTT } \\
\text { ACTGGCTTAATCAATTTGGG }\end{array}$ \\
\hline catA & + & $\begin{array}{l}\text { GCCTTTCCGCCACCTCACCG } \\
\text { GGATATGAAATTTATCCCTC }\end{array}$ \\
\hline vat $\mathrm{E}$ & - & $\begin{array}{l}\text { CAATCATCTACCCTATGAAT } \\
\text { ACGTTACCCATCACTATG }\end{array}$ \\
\hline$b c r \mathrm{~B}$ & - & $\begin{array}{l}\text { GCTCCGATAATGGCACCGAC } \\
\text { AAAGAAACCGACTGCTGATA }\end{array}$ \\
\hline$b c r \mathrm{D}$ & - & $\begin{array}{l}\text { GCTTACTTGTATAGCAGAGA } \\
\text { AGGATTCGGCCGAATGGCACTTGATTTTAT }\end{array}$ \\
\hline$b c r \mathrm{R}$ & - & $\begin{array}{l}\text { GTTTCTTCGCGAAATTGCCGTTATAAGTAA } \\
\text { AACAAACAGGGAGCGGCCGCATGGAATTTA }\end{array}$ \\
\hline$d d l \mathrm{E}$ & - & $\begin{array}{l}\text { TGATGTTCGCGATTTCATTCCCATCTGCTT } \\
\text { ATCAAGTACAGTTAGTCT }\end{array}$ \\
\hline
\end{tabular}

Primers $\left(5^{\prime}-3^{\prime}\right)$

(2)

(1)

.


Table 1 (continued)

\begin{tabular}{|c|c|c|}
\hline & $\begin{array}{l}\text { Presence of virulence } \\
\text { factor gene on genome } \\
\text { of } L b \text {. plantarum ST8Sh }\end{array}$ & Primers $\left(5^{\prime}-3^{\prime}\right)$ \\
\hline $\operatorname{aac}\left(6^{\prime}\right)-\mathrm{Ii}$ & - & $\begin{array}{l}\text { ACGATTCAAAGCTAACTG } \\
\text { GCGGTAGCAGCGGTAGACCAAG }\end{array}$ \\
\hline mur2ed & - & $\begin{array}{l}\text { GCATTTGGTAAGACACCTACG } \\
\text { AACAGCTTACTTGACTGGACGC }\end{array}$ \\
\hline mur2 & - & $\begin{array}{l}\text { GTATTGGCGCTACTACCCGTATC } \\
\text { CGTCAGTACCCTTCTTTTGCAGAGTC }\end{array}$ \\
\hline$c c f$ & - & $\begin{array}{l}\text { GCATTATTACCAGTGTTAGTGGTTG } \\
\text { GGGAATTGAGTAGTGAAGAAG }\end{array}$ \\
\hline$c o b$ & + & $\begin{array}{l}\text { AGCCGCTAAAATCGGTAAAAT } \\
\text { AACATTCAGCAAACAAAGC }\end{array}$ \\
\hline cpd & + & $\begin{array}{l}\text { TTGTCATAAAGAGTGGTCAT } \\
\text { TGGTGGGTTATTTTTCAATTC }\end{array}$ \\
\hline int & + & $\begin{array}{l}\text { TACGGCTCTGGCTTACTA } \\
\text { GCGTGATTGTATCTCACT }\end{array}$ \\
\hline $\operatorname{spr} \mathrm{E}$ & - & $\begin{array}{l}\text { GACGCTCCTGTTGCTTCT } \\
\text { TTGAGCTCCGTTCCTGCCGAAAGTCATTC }\end{array}$ \\
\hline$f_{s r} \mathrm{~A}$ & - & $\begin{array}{l}\text { TTGGTACCGATTGGGGAACCAGATTGACC } \\
\text { ATGAGTGAACAAATGGCTATTTA }\end{array}$ \\
\hline$f_{s r} \mathrm{~B}$ & - & $\begin{array}{l}\text { CTAAGTAAGAAATAGTGCCTTGA } \\
\text { GGGAGCTCTGGACAAAGTATTATCTAACCG }\end{array}$ \\
\hline$f_{s r} \mathrm{C}$ & - & $\begin{array}{l}\text { TTGGTACCCACACCATCACTGACTTTTGC } \\
\text { ATGATTTTGTCGTTATTAGCTACT }\end{array}$ \\
\hline int-Tn & - & $\begin{array}{l}\text { CATCGTTAACAACTTTTTTACTG } \\
\text { TGACACTCTGCCAGCTTTAC }\end{array}$ \\
\hline $\operatorname{Van} \mathrm{A}$ & - & $\begin{array}{l}\text { CCATAGGAACTTGACGTTCG } \\
\text { TCTGCAATAGAGATAGCCGC }\end{array}$ \\
\hline $\operatorname{Van} \mathrm{B}$ & - & $\begin{array}{l}\text { GGAGTAGCTATCCCAGCATT } \\
\text { GCTCCGCAGCCTGCATGGACA }\end{array}$ \\
\hline $\operatorname{Van} \mathrm{C} 1$ & + & $\begin{array}{l}\text { ACGATGCCGCCATCCTCCTGC } \\
\text { GGTATCAAGGAAACCTC }\end{array}$ \\
\hline $\operatorname{Van} \mathrm{C} 2$ & - & $\begin{array}{l}\text { CTTCCGCCATCATAGCT } \\
\text { CTCCTACGATTCTCTTG }\end{array}$ \\
\hline $\operatorname{van} \mathrm{C} 1(2)$ & - & $\begin{array}{l}\text { CGAGCAAGACCTTTAAG } \\
\text { GCTGAAATATGAAGTAATGACC }\end{array}$ \\
\hline $\operatorname{van} \mathrm{C} 2 / \mathrm{C} 3$ & - & $\begin{array}{l}\text { CGGCATGGTGTTGATTTCGTT } \\
\text { CTCCTACGATTCTCTTG }\end{array}$ \\
\hline$h d c 1$ & - & $\begin{array}{l}\text { CGAGCAAGACCTTTAAG } \\
\text { AGATGGTATTGTTTCTTATG }\end{array}$ \\
\hline$h d c 2$ & - & $\begin{array}{l}\text { AGACCATACACCATAACCTT } \\
\text { AAYTCNTTYGAYTTYGARAARGARG }\end{array}$ \\
\hline$t d c$ & - & $\begin{array}{l}\text { ATNGGNGANCCDATCATYTTRTGNCC } \\
\text { GAYATNATNGGNATNGGNYTNGAYCARG }\end{array}$ \\
\hline odc & - & $\begin{array}{l}\text { CCRTARTCNGGNATAGCRAARTCNGTRTG } \\
\text { GTNTTYAAYGCNGAYAARCANTAYTTYGT }\end{array}$ \\
\hline & & ATNGARTTNAGTTCRCAYTTYTCNGG \\
\hline
\end{tabular}

Positive results (+) for genes for virulence, antibiotic resistance, and biogenic amines in $L b$. plantarum ST8Sh

\section{Results and Discussion}

\section{Bacteriocin Partial Purification and Cytotoxocity Test}

Bacteriocin produced by $L b$. plantarum ST8Sh has been partially purified by ammonium sulfate precipitation and hydrophobic chromatography on $\mathrm{SepPakC}_{18}$ column. The semi-purified bacteriocin showed an exceptionally high activity against L. monocytogenes $(102,400 \mathrm{AU} / \mathrm{mL})$ and E. faecalis $(102,400 \mathrm{AU} / \mathrm{mL})$. Semi-purified fractions $(60 \%$ iso-propanol and $80 \%$ iso-propanol) of bacteriocin ST8Sh were tested on Huh7.5 cells for their cytotoxicity profile. At 
Table 2 Effect of commercial drugs on the growth of Lb. plantarum ST8Sh, presented as diameter of inhibition zones in millimeters and Minimal Inhibition Concentration (MIC)

\begin{tabular}{|c|c|c|c|c|}
\hline Commercial name & $\begin{array}{l}\text { Concentration } \\
(\mathrm{mg} / \mathrm{mL})\end{array}$ & Active substance & Medicament class & $\begin{array}{l}\text { Lb. plantarum ST8Sh } \\
\text { Inhibition zone }(\mathrm{mm}) \\
{[\mathrm{MIC}(\mathrm{mg} / \mathrm{mL})]}\end{array}$ \\
\hline Amoxil & 100 & Amoxicillin & $\beta$-Lactam antibiotic (Penicillin) & $\begin{array}{l}32 \\
{[<0.4]}\end{array}$ \\
\hline Arotin & 4 & Paroxetine & $\begin{array}{l}\text { Selective serotonin reuptake inhibitor } \\
\text { (SSRI) antidepressant }\end{array}$ & $\begin{array}{l}10 \\
{[2.0]}\end{array}$ \\
\hline Atlansil & 40 & Amiodarone & Antiarrhythmic & $\begin{array}{l}14 \\
{[1.25]}\end{array}$ \\
\hline Cataflam & 10 & Diclofenac potassium & Non-steroidal anti-inflammatory drug (NSAID) & $\begin{array}{l}10 \\
{[10.0]}\end{array}$ \\
\hline Diclofenaco potassico* & 10 & Diclofenac potassium & NSAID & $\begin{array}{l}12 \\
{[20.0]}\end{array}$ \\
\hline Diclofenaco potassico* & 10 & Diclofenac potassium & NSAID & $\begin{array}{l}10 \\
{[20 \cdot 0]}\end{array}$ \\
\hline Dorflex & 10 & $\begin{array}{l}\text { Orphenadrine citrate, Metamizole } \\
\text { sodium, Cafein }\end{array}$ & Analgesic & $\begin{array}{l}10 \\
{[5.0]}\end{array}$ \\
\hline Fenergan & 5 & Promethazine hydrochloride & Antihistaminic & $\begin{array}{l}10 \\
{[5.0]}\end{array}$ \\
\hline Spidufen & 120 & Ibuprofen arginine & NSAID & $\begin{array}{l}16 \\
{[30.0]}\end{array}$ \\
\hline
\end{tabular}

Following commercial drugs has no effect on the growth of $L$ b. plantarum ST8Sh — AAS (Acetylsalicylic acid, Analgesic/Antipyretic at 20 mg/mL); Antak (Ranitidine hydrochloride, Histamine H2-receptor antagonist that inhibits stomach acid production (Proton pump inhibitor) at $30 \mathrm{mg} / \mathrm{mL}$ ); Aspirina (Acetylsalicylic acid, Analgesic/Antipyretic at $100 \mathrm{mg} / \mathrm{mL}$ ); Celebra (Celecoxib, NSAID at $40 \mathrm{mg} / \mathrm{mL}$ ); Clorana (Hydrochlorothiazide, Diuretic at $5 \mathrm{mg} / \mathrm{mL}$ ); Coristina R (Acetylsalicylic acid, Pheniramine maleate, Phenylephrine hydrochloride, Cafein, Analgesic/Antipyretic/ Antihistaminic/Decongestant at $10 \mathrm{mg} / \mathrm{mL}$ ); Doxuran (Doxazosin, Antihypertensive/Treatment of prostatic hyperplasia at $0.8 \mathrm{mg} / \mathrm{mL}$ ); Dramin (Dimenhydrinate, Antiemetic at $20 \mathrm{mg} / \mathrm{mL}$ ); Fluimucil (Acetylcysteine, Mucolitic agent at $8 \mathrm{mg} / \mathrm{mL}$ ); Flutec (Fluconazole, Antifungal at $30 \mathrm{mg} / \mathrm{mL}$ ); Higroton (Chlorthalidone, Thiazide diuretic at $10 \mathrm{mg} / \mathrm{mL}$ ); Neosaldina (Metamizole sodium, isometheptenemucate, cafein, Analgesic at $60 \mathrm{mg} / \mathrm{mL}$ ); Nimesulida (Nimesulide, NSAID at $20 \mathrm{mg} / \mathrm{mL}$ ); Nisulid (Nimesulide, NSAID at $20 \mathrm{mg} / \mathrm{mL}$ ); Omeprazol (Omeprazole, Proton pump inhibitor at $4 \mathrm{mg} /$ $\mathrm{mL}$ ); Redulip (Sibutramine hydrochloride monohydrate, Anorexiant/Sympathomimetic at $3 \mathrm{mg} / \mathrm{mL}$ ); Seki (Cloperastine, Antitussives (central and periferic mode of action) at $3.54 \mathrm{mg} / \mathrm{mL}$ ); Superhist (Acetylsalicylic acid, Pheniramine maleate, Phenylephrine hydrochloride, Analgesic/Antipyretic/ Antihistaminic/Decongestant at $80 \mathrm{mg} / \mathrm{mL}$ ); Tylenol (Paracetamol, Analgesic/Antipyretic at $150 \mathrm{mg} / \mathrm{mL}$ ); Tylex (Paracetamol, Codein, Analgesic at $6 \mathrm{mg} / \mathrm{mL}$ ); Yasmin (Ethinylestradiol, drospirenone, Contraceptive at $0.6 \mathrm{mg} / \mathrm{mL}$ ); Zestril (Lisinopril, Antihypertensive (Angiotensin-converting enzyme (ACE) inhibitor) at $4 \mathrm{mg} / \mathrm{mL}$ ); Zocor (Simvastatin, Hypolipidemic at $2 \mathrm{mg} / \mathrm{mL}$ ); and Zyrtec (Cetirizine hydrochloride, Antihistaminic at $2 \mathrm{mg} / \mathrm{mL}$ )

*Produced by two different companies

concentration of $25 \mu \mathrm{g} / \mathrm{mL}, 60 \%$ fraction demonstrated to be highly cytotoxic, reducing the cell viability by approximately $80 \%$; however, when this same fraction was tested at a lower concentration $(5 \mu \mathrm{g} / \mathrm{mL})$, no cell cytotoxicity was observed. Regarding the $80 \%$ iso-propanol fraction, cell viability was not reduced in both tested concentrations ( 25 and $5 \mu \mathrm{g} / \mathrm{mL}$ ). Moreover, it is essential to pay attention to the cytotoxicity of this and similar bacteriocins in food preparations, due to their potential of concentration depending on the effect on cell viability that may result in severe side effects and tissue damage if ingested by humans or other animal bacteriocins.

Analysis of bacteriocin cytotoxicity is not a routine procedure, and only a few studies on this issue are available in literature. In a previous study, our group demonstrated a high cytotoxicity potential of two other bacteriocins (ST202Ch and ST216Ch) on Huh7.5 cells [24]. Vaucher et al. [25] evaluated the toxicity profile of the commercial bacteriocins on epithelial monkey kidney cells (Vero), and it was demonstrated that at $1.04 \mu \mathrm{g} / \mathrm{mL}$ concentrations, nisin reduced the cell viability by $50 \%$. Therefore, concerning cell cytotoxicity, semi-purified fractions of bacteriocin ST8Sh appear to be safer for practical use than nisin. Although their excellent potential as food preservatives and antibiotic substitutes, bacteriocins can also be toxic to human cells, and so, cytotoxicity assays should be included as routine in research on bacteriocins to be used as biopreservatives.

\section{Screening for the Presence of Virulence Factors}

Lb. plantarum ST8Sh showed a low presence of virulence genes. Only 13 genes were detected (related to sex pheromones, aggregation substance, adhesion of collagen, tetracycline, gentamicin, chloramphenicol, erythromycin, but not to vancomycin and bacitracin) and may be considered as safe for application in fermented food products (Table 1). The detected frequency of possible presence of the virulence factors in $L b$. 
plantarum ST8Sh was lower than that reported in other studies on Lactobacillus spp. and Enterococcus spp. isolated from foods [19, 20, 26-28] and also in comparison to studies with clinical isolates [20, 29, 30]. Lb. plantarum ST16Pa [31] isolated from papaya was previously described with positive PCR results for the presence of gelE (gelatinase), hyl (hyaluronidase), asa1 (aggregation substance), ace (adhesion of collagen), and $t d c$ (tyrosine decarboxylase), thus representing a high virulence profile when compared to the results obtained in the present study for Lb. plantarum ST8Sh.

Even when the presence of virulence factors was less relevant to $\mathrm{LAB}$ strains isolated from food, compared to $\mathrm{LAB}$ from clinical origin, the determination of virulence factors in $\mathrm{LAB}$ by molecular and phenotypic procedures is important due to the risk of gene transfer, since these factors are usually encoded by genes located in conjugative plasmids [30]. The $\mathrm{LAB}$ comprises a heterologous group of six families and at least 36 different genera with particular metabolism, but with common characteristics including their fermentative ability to produce lactic acid as a major end product of primary metabolism [5, 32]. Several LAB have a long history as beneficial organisms, used in or associated with different fermentation processes and applied as probiotics [1]. However, some LAB are considered as opportunistic pathogens and have been associated with some clinical cases [2-4]. Some enterococci may contain several determinants of pathogenicity, such as colonization factors that promote the adhesion of bacteria to host cells and invasion factors that promote the invasion of epithelial cells disordering the immune system [29, 33]. Different cell wall-anchored surface proteins are related to enterococcal pathogenicity, including aggregation substance, enterococcal surface protein, and collagen binding components [34]. The presence of enterococcal surface proteins, including aggregation substance, Enterococcus surface protein, adhesins, and other adhesive molecules, such as Enterococcus endocarditis antigen may facilitate close contact between cells for conjugation and subsequent transfer of virulence plasmids [34]. However, on the other side, they can be involved in better adhesion and colonization of the GIT. On the negative side, the aggregation substance protein may have a role in translocation of enterococci into epithelial cells [35] and be involved in the pathogenicity of these bacteria. A cell wallanchored protein characterized by its ability to form biofilms, e.g., Enterococcus surface protein, may therefore be implicated in enterococcal infections associated with biofilms [34].

In the last two decades, the term as quorum sensing (QS) was extensively explored and defined as an intercellular chemical signaling system in bacteria. Related to this, production and detection of compounds known as pheromones to elicit coordinated responses among members of a bacterial community was described [36]. Pheromones produced by Gram-positive bacteria comprise small peptides. These peptides can be related to different key regulatory processes in bacterial cells, including a variety of fundamental behaviors including conjugation, natural competence for transformation, biofilm development, and virulence factor regulation. Even if not much work has been conducted on Lactobacillus spp. related to peptide pheromones, we need to be aware that this process is relevant to all bacterial groups. Genes related to production and expression of peptide pheromones can be a part of the natural genome of bacterial species, but can be a result of the horizontal gene transfer within and between species via conjugative plasmids. Generally, conjugation, well studied in Enterococcus spp., is controlled via peptide pheromones [36]. The possible presence of bacterial pheromone genes in Lb. plantarum ST8Sh needs to be explored in more details in order to give an answer on their exact role in the genus Lactobacillus and Lb. plantarum particularly. Are these genes a part of the natural genetic heritage of the species or are they appearing as a result of inter-bacterial interaction and horizontal gene transfer?

Based on the performed phenotypic tests, $L b$. plantarum ST8Sh was not expressing any of the tested virulence factors. These results can be related to the fact that expression of studied virulence factors may be related either to the specific growth condition for the tested Lb. plantarum ST8Sh strain, or to the more complex condition/interaction with different factors. Or simply, most probably, the genes encoding this virulence factors are partially inactivated or parts of the operon are damaged or just not present.

\section{Effect of Commercial Drugs on Lb. plantarum ST8Sh}

Application of probiotics is related to the prevention/ prophylaxis of diseases; however, they form part of the active therapy as well. Most frequently individuals or patients taking probiotics are often treated for other illnesses, including chronic clinical cases. However, are we aware of possible interactions between viable probiotics and drugs as chemical substances? As we need to optimize the effect of the probiotics to the host, it is important to determine the effect of drugs on the survival of probiotic strains. As presented in Table 2, the tested $\mathrm{Lb}$. plantarum ST8Sh strain was inhibited by nonsteroidal anti-inflammatory drugs (NSAID) containing diclofenac potassium, ibuprofen arginine, promethazine hydrochloride, paroxetine, amiodarone, Dorflex, an analgesic that contains orphenadrine citrate, metamizole sodium, and cafein. In addition, $L b$. plantarum ST8Sh expectedly was sensitive to amoxyl. However, inhibition of $L$ b. plantarum ST8Sh needs to be considered not as qualitative interaction, but in relation of the observed MIC, presented on Table 2. In addition to previous, it is important to mention that the concentration of these drugs/substances in the GIT, together with MIC, is critical for their interaction with the probiotic bacteria $[6,7]$. In this regard, considering that the daily dose for Spidufen is $600 \mathrm{mg}$ (Zambon Laboratórios Farmacêuticos Ltda), the MIC 
Table 3 Effect of antibiotics on the growth of Lactobacillus plantarum ST8Sh, presented as diameter of inhibition zones in millimeters

\begin{tabular}{|c|c|c|}
\hline Antibiotic $(\mu \mathrm{g} /$ disk $)$ & Classification & $\begin{array}{l}\text { Inhibition } \\
\text { zone }(\mathrm{mm})\end{array}$ \\
\hline Ampicillin, 10 & Penicillins/ $\beta$-Lactam (interferes with bacteria cell wall synthesis) & 38 \\
\hline Bacitracin, 10 & Cyclic polipeptide (inhibits bacteria cell wall synthesis) & 22 \\
\hline Cefazolin, 30 & 1 st generation cephalosporin/ $\beta$-Lactam (interferes with bacteria cell wall synthesis) & 23 \\
\hline Cefepime, 30 & 4 th generation cephalosporin $/ \beta$-Lactam (interferes with bacteria cell wall synthesis) & 21 \\
\hline Cefotaxim, 30 & 2nd generation cephalosporin/ $\beta$-Lactam (interferes with bacteria cell wall synthesis) & 23 \\
\hline Ceftazidim, 30 & 3 th generation cephalosporin/ $\beta$-Lactam (interferes with bacteria cell wall synthesis) & 18 \\
\hline Ceftriaxon, 30 & 3 th generation cephalosporin/ $\beta$-Lactam (interferes with bacteria cell wall synthesis) & 16 \\
\hline Cefuroxim, 30 & $\beta$-Lactam (interferes with bacteria cell wall synthesis) & 19 \\
\hline Ciprofloxacin, 5 & Fluoroquinolones (inhibits the bacterial topoisomerase II) & 12 \\
\hline Clindamicin, 2 & Licosamides (inhibits protein synthesis) & 32 \\
\hline Chloramphenicol, 30 & Prevents peptide bond formation-inhibits protein synthesis) & 27 \\
\hline Erytromicin, 15 & Macrolide (inhibits protein synthesis) & 21 \\
\hline Furazolidon, 10 & Antibiotic/antiparasitic & 15 \\
\hline Gentamicin, 10 & Aminoglycoside (inhibits protein synthesis) & 10 \\
\hline Imipenem, 10 & Carbapenem $/ \beta$-Lactam (interferes with bacteria cell wall synthesis) & 36 \\
\hline Neomicin, 30 & Aminoglycosides (inhibit protein synthesis) & 12 \\
\hline Nitrofurantoin, 300 & Nitrofuran derivative (nucleic acid inhibitor) & 21 \\
\hline Ofloxacin, 5 & Licosamide (inhibits protein synthesis) & 12 \\
\hline Penicillin G, 10 & $\beta$-Lactam (interferes with bacteria cell wall synthesis) & 14 \\
\hline Rifampicin, 30 & Semisynthetic compound derived from Amycolatopsisrifamycinica & 25 \\
\hline Rifampicin, 5 & Semisynthetic compound derived from Amycolatopsisrifamycinica & 21 \\
\hline Streptomicin, 10 & Aminoglycoside (inhibits protein synthesis) & 20 \\
\hline Tetraciclin, 30 & (inhibits protein synthesis) & 27 \\
\hline Trimetoprim, 5 & (Inhibits folatesyntesis) & 22 \\
\hline
\end{tabular}

Amicacin $30 \mu \mathrm{g} /$ disk and Kanamicin $30 \mu \mathrm{g} /$ disk (Aminoglycoside, inhibits protein synthesis), Metronidazol $50 \mu \mathrm{g} / \mathrm{disk}$ (Nitroimidazole antibiotic, acts on DNA of microorganisms, ameba, and protozoa), Nalidixic acid $30 \mu \mathrm{g} /$ disk (Syntetic quinolone antibiotic, acts on DNA gyrase), Oxacilin $1 \mu \mathrm{g} / \mathrm{disk}$ ( $\beta$-Lactam, interferes with bacteria cell wall synthesis), Tobramicin $10 \mu \mathrm{g} / \mathrm{disk}$ (Aminoglycoside, inhibits protein synthesis), and Vancomycin $30 \mu \mathrm{g} /$ disk (Glycopeptide, inhibits bacteria cell wall synthesis) are not affecting the growth of $L b$. plantarum ST8Sh

${ }^{a}$ Average diameter of inhibition zones of the test microorganism

value associated to the volume of the human GIT indicates that the recommended daily dose will hardly affect the survival of $L b$. plantarum ST8Sh. However, more important are the drugs used in the treatment of chronic diseases, since the higher concentrations may be accumulated in the human body, including the GIT. Atlansilis, an anti-arrhytmic drug is normally used in long-term treatments; Fenergan, an antihistaminic drug, and Arotin, a drug from the group of the antidepressants with neuroleptic effect, are also used in longterm treatments and presented an MIC of 1.25, 5.0, and $2.0 \mathrm{mg} / \mathrm{mL}$, respectively. Due to their long-term application, these drugs may accumulate in the GIT and MIC-values which may be reached that may affect viability of $L b$. plantarum ST8Sh.

The interaction between anti-inflammatory drugs based on diclofenac and LAB detected in this study (Table 2) was also reported previously in other studies. It has been reported that this group of drugs inhibited the growth of $L b$. plantarum ST8KF and ST341LD, E. faecium ST311LD, and Leuconostoc mesenteroides subsp. mesenteroides ST33LD [31]. In a similar study, potassium diclofenac and ibuprofen inhibited the growth of Lactococcus lactis subsp. lactis HV219 [6]; Lb. casei Shirota and $L b$. casei $\mathrm{LC} 01$ were inhibited by non-steroidal anti-inflammatory drugs (NSAID) containing diclofenac potassium or ibuprofen arginine [8]. In addition, Carvalho et al. (11) reported that Lb. casei Shirota was affected by selective serotonin reuptake inhibitors (SSRI), an antidepressant containing paroxetine, and antiarrhythmic medicine containing amiodarone, while $\mathrm{Lb}$. casei LC01 was inhibited by hypolipidemic drugs containing simvastatin. Anti-inflammatory drugs, moderate diuretic and neuroleptic containing potassium or sodium diclofenac, ibuprofen, triamterene hydrochlorothiaziden, and thioridazinehydrochlorid acted as inhibitors of $L b$. plantarum, Lb. rhamnosus, $L b$. paracasei, and $L b$. pentosus strains isolated from boza and tested for probiotic potential [7]. It is extremely difficult to compare results working with different strains, due to the fact that 
drug/bacteria interactions are strain specific, this also being observed when authors explored different strains of the same species in one study [7]. However, it is interesting and also important to compare results obtained with some commercial and/or reference strains as reported by different research groups. Botes et al. [37] found that $L b$. casei Shirota was inhibited by several commercial antibiotics, in addition to the anti-inflammatory drugs containing meloxican (Coxflam), Ibuprofen (Dolocyl, Adco-Ibuprofen), potassium diclofenac (Cataflam), and prednisolone (Preflam) that also inhibited the strain growth, to a lesser extent. Pinmed, containing paracetamol, codeine phosphate, and promethazine $\mathrm{HCl}$, misclassified as analgesic instead of an antitussive agent, was also inhibitory to $L$. casei Shirota. The same authors also reported the inhibitory effect of Pynmed, more likely due to the presence of alcohol in the formulation than to the drug itself [37]. This is another important point that needs to be taken into account - the composition of the drug preparation and the presence and composition of the accompanying substrate or solvent.

Among the tested drugs in this study, the anti-inflammatory medical preparations were those that affected $L b$. plantarum ST8Sh more significantly. These results are in agreement with previous studies, investigating other potential probiotics and commercial LAB probiotics $[6-8,37,38]$. Taking into consideration the composition of the mentioned drugs, their inhibitory activity may be related to an increased concentration of potassium ions in the gastric content as a result of the dissociation of potassium diclofenac in the GIT. The excess of potassium ions in the environment is incompatible with microbial cell viability and may have a negative effect on LAB. Other potassium-based drugs may cause a similar negative effect. Individuals under permanent therapy with drugs should be aware that these drugs may reduce the beneficial effects of the probiotic bacteria.

\section{Resistance to Antibiotics}

The majority of the investigated antibiotics in this study inhibited the growth of $L b$. plantarum ST8Sh (Table 3). Growth of Lb. plantarum ST8Sh was not affected by the presence of Amicacin $(30 \mu \mathrm{g} /$ disk $)$ and Kanamicin $(30 \mu \mathrm{g} / \mathrm{disk})$ (Aminoglycoside, inhibits protein synthesis), Metronidazol $(50 \mu \mathrm{g} /$ disk) (Nitroimidazole antibiotic, acts on DNA of microorganisms, amoeba, and protozoa), Nalidixic acid (30 $\mu \mathrm{g} /$ disk) (Synthetic quinolone antibiotic acts on DNA gyrase), Oxacilin $(1 \mu \mathrm{g} /$ disk $)(\beta$-Lactam, interferes with bacteria cell wall synthesis), Tobramicin (10 $\mu \mathrm{g} /$ disk) (Aminoglycoside, inhibits protein synthesis), and Vancomicin $(30 \mu \mathrm{g} /$ disk $)$ (Glycopeptide, inhibits bacteria cell wall synthesis). Resistance of potential probiotic LAB candidates to antibiotics is a controversial subject, as these strains may be reservoirs of antibiotic resistance genes, and can be transferred horizontally to other bacteria in the human and other animals
GIT [5]. However, from another point of consideration, resistance to antibiotics can be considered as a positive aspect, since such LAB strains (carrying resistance to a specific antibiotic) could be applied in combination with such an antibiotic potentially resulting in synergism between the antibiotic and the LAB strain in the treatment of the diseases. Resistance may be inherent to a bacterial genus or species, but may also be acquired through exchange of genetic material, mutations, and the incorporation of new genes [23, 39-41].

Presence of genes related to tetracycline, gentamicin, chloramphenicol, erythromycin antibiotic resistance was detected in Lb. plantarum ST8Sh. Lactobacilli have a high natural (constitutive) resistance to different antibiotics, including gentamicin [42]. In addition, many strains of Lb. plantarum are intrinsically resistant to the antibiotic, due to the presence of D-alanine-D-alanine ligase related enzymes [43]. Salminen et al. [44] showed that strains of Lactobacillus isolated from blood samples had low MIC values to erythromycin in addition to other antibiotics. However, lactobacilli are generally susceptible to antibiotics interfering with protein synthesis, e.g., chloramphenicol, erythromycin, clindamycin and tetracycline, but are more resistant to aminoglycosides (neomycin, kanamycin, streptomycin, and gentamicin) [45-47]. In general, lactobacilli show resistance to most inhibitors of nucleic acid synthesis, including enoxacin, pefloxacin, norfloxacin, nalidixic acid, sulphamethoxazole, trimethoprim, cotrimoxazole, and metronidazole [45, 46]. Herreros et al. [48] reported on resistance to tetracycline in $\mathrm{Lb}$. plantrum isolated from Armada cheese. Tetracycline resistance was recorded for several strains of $L b$. plantarum isolated from raw milk soft cheeses [23]. Lb. plantarum isolated from "home-made" Spanish cheese (Serena, Gamonedo and Cabrales) revealed resistance to penicillin $G$, cloxacillin, streptomycin, gentamycin, tetracycline, erythromycin, and chloramphenicol [49]. Regarding gentamicin, MIC values detected in wine isolates of $L b$. plantarum were in general very high. A similar observation was reported by Elkins and Mullis [50] in who found intrinsic resistance of lactobacilli to aminoglycosides to be due to membrane impermeability, probably complemented by potential efflux mechanisms. In general, $L b$. plantarum showed higher MICs for aminoglycosides than other LAB genera and Lactobacillus species [51]. Conversely, Zhou et al. [47] found almost all out of ten tested $L b$. plantarum strains to be resistant to gentamicin.

The antibiotic resistance genes provide elevated competition potential to a strain to survive and constitute a positive attribute to survival and adaptation. From the human point of view, these genes are generally undesirable. Lactobacilli are generally susceptible to antibiotics inhibiting the synthesis of proteins, such as chloramphenicol, erythromycin, clindamycin, and tetracycline, and more resistant to aminoglycosides (neomycin, kanamycin, streptomycin, and gentamicin) [5]. However, strains resistant to these antibiotic agents 
have also been identified [5], and several genes providing such resistance have been studied; e.g., a chloramphenicol resistance gene (cat) has been detected in Lb. plantarum [52]. Also, different erythromycin-resistance genes ( $\mathrm{erm}$ ) have been found in many species, as well as a number of tetracycline resistance genes [5]. The tet $\mathrm{S}$ gene in the probiotic Lb. plantarum strain CCUG 43738 was found to be located on a plasmid of 14-kbp [53].

The major financial and societal costs caused by the increase in antibiotic resistance in pathogenic microorganisms are a general issue of concern. The attenuation of this problem is complicated by commercial bacteria that may act as reservoirs for antibiotic resistance determinants found in pathogens $[40,54]$. This statement is supported by the fact that the same type of genes encoding resistance to, for example, tetracycline, erythromycin, chloramphenicol, streptomycin, and streptogramin, have been found in commercial lactococci and lactobacilli as well as in potentially pathogenic enterococci and pathogenic streptococci [23]. A most important similarity in resistance genes has also been observed for tetracycline-resistance in $L b$. plantarum and other LAB [5, $55]$.

\section{Conclusions}

Besides, all beneficial properties studied for various LAB, most considered as GRAS, special attention needs to be given to the possible presence of virulence factors, production of biogenic , and antibiotic resistance. These virulence determinants have been detected and well studied in enterococci and streptococci; however, in the last few years, reports on the presence of virulence factors in otherwise GRAS lactobacilli have indicated potential upcoming problems. Horizontal gene transfer of virulence factors between pathogenic and LAB, including probiotics, appears to be a highly possible scenario in case of uncontrolled application of probiotics. Complex research of all aspects of potential new probiotics strains and antimicrobial peptides is essential in order to ensure safety application of these strains and/or their metabolites.

\begin{abstract}
Acknowledgements This work has been supported by research and personal grants from FAPEMIG (Belo Horizonte, MG, Brazil), CAPES (Brasilia, DF, Brazil), and CNPq (Brasilia, DF, Brazil). To Braga A.C.S. and Batista M.N. from UNESP - Universidade Estadual Paulista, Instituto de Biociências, Letras e Ciências Exatas. Departamento de Engenharia e Tecnologia de Alimentos, São José do Rio Preto, SP, Brazil for technical assistance related to cytotoxicity of bacteriocin work.
\end{abstract}

\section{Compliance with Ethical Standards}

Conflict of Interest The authors declare that they have no conflict of interest.

\section{References}

1. Martinez RCR, Vieira ADS, Santos KMO, Franco BDGM, Todorov SD (2012) Characterization and evaluation of Lactobacillus plantarum probiotic potential. In: AIP C, Mena AL (eds) Lactobacillus: classification, uses and health implications, Bacteriology Research Developments / Microbiology Research Advances series. Nova Publishers, New York, USA, pp 36-63

2. Doern CD, Nguyen ST, Afolabi F, Burnham C-AD (2014) Probiotic-associated aspiration pneumonia due to Lactobacillus rhamnosus. J Clin Microbiol 52:3124-3126

3. Goldstein EJC, Tyrrell KL, Citron DM (2015) Lactobacillus species: taxonomic complexity and controversial susceptibilities. Clin Infect Dis 60:S98-S107

4. Schwendicke F, Dörfer C, Kneist S, Meyer-Lueckel H, Paris S (2014) Cariogenic effects of probiotic Lactobacillus rhamnosus GG in a dental biofilm model. Caries Res 48:186-192

5. Dicks LMT, Todorov SD, Franco BDGM (2011) Current status of antibiotic resistance in lactic acid bacteria. In: Bonilla AR, Muniz KP (eds) Antibiotic resistance: causes and risk factors, mechanisms and alternatives. Pharmacology — research, safety testing and regulation. Nova Publisher, New York, USA, pp 379-425

6. Todorov SD, Botes M, Danova ST, Dicks LMT (2007) Probiotic properties of Lactococcus lactis subsp. lactis HV219, isolated from human vaginal secretions. J Appl Microbiol 103:629-639

7. Todorov SD, Botes M, Guigas C, Schillinger U, Wiid I, Wachsman MB, Holzapfel WH, Dicks LMT (2008) Boza, a natural source of probiotic lactic acid bacteria. J Appl Microbiol 104:465-477

8. De Carvalho KG, Kruger MF, Furtado DN, Todorov SD, Franco BDGM (2009) Evaluation of the role of environmental factors in the human gastrointestinal tract on the behaviour of probiotic cultures Lactobacillus casei Shirota and Lactobacillus casei $\mathrm{LC} 01$ by the use of a semi-dynamic in vitro model. Ann Microbiol 59:439-445

9. Bogsan CS, Nero LA, Todorov SD (2015) From traditional knowledge to an innovative approach for bio-preservation in food by using lactic acid bacteria.Chapter 01. In: Liong M-T (ed) Beneficial microorganisms in Food \& Nutraceuticals. Springer, New York, NY, USA, pp 1-36

10. Jozala AF, De Andrade MS, De Arauz LJ, Pessoa A Jr, Penna TCV (2007) Nisin production utilizing skimmed milk aiming to reduce process cost. Appl Biochem Biotechnol 137-140:515-528

11. Deegan LH, Cotter PD, Hill C, Ross P (2006) Bacteriocins: biological tools for bio-preservation and shelf-life extension. Int Dairy $\mathrm{J}$ 16:1058-1071

12. Motta AS, Cannavan FS, Tsai S-M, Brandelli A (2007) Characterization of a broad range antibacterial substances from a new Bacillus species isolated from Amazon basin. Arch Microbiol 188:367-375

13. Vaucher AR, Gewehr CVC, Correa FAP, Sant'Anna V, Ferreira J, Brandelli A (2011) Evaluation of the immunogenicity and in vivo toxicity of the antimicrobial peptide P34. Int J Pharm 421:94-98

14. Klaenhammer TR (1988) Bacteriocins of lactic acid bacteria. Biochimie 70:337-349

15. Todorov SD, Holzapfel W, Nero LA (2016) Characterization of a novel bacteriocin produced by Lactobacillus plantarum ST8SH and some aspects of its mode of action. Ann Microbiol 66:949-962

16. Todorov SD, Holzapfel WH, Nero LA (2016) In Vitro evaluation of beneficial properties of bacteriocinogenic Lactobacillus plantarum ST8Sh. Probiotics \& Antimicrobial Proteins. doi:10.1007/s12602016-9245-7. (in press)

17. Moraes PM, Perin LM, Todorov SD, Silva A Jr, Franco BDGM, Nero LA (2012) Bacteriocinogenic and virulence potential of Enterococcus isolates obtained from raw milk and cheese. J Appl Microbiol 113:318-328 
18. Fortina MG, Ricci G, Borgo F, Manachini PL, Arends K, Schiwon K, Abajy MY, Grohmann E (2008) A survey on biotechnological potential and safety of the novel Enterococcus species of dairy origin, E. italicus. Int J Food Microbiol 123:204-211

19. Barbosa J, Gibbs PA, Teixeira P (2010) Virulence factors among enterococci isolated from traditional fermented meat products produced in the north of Portugal. Food Control 21:651-656

20. Eaton TJ, Gasson MJ (2001) Molecular screening of Enterococcus virulence determinants and potential for genetic exchange between food and medical isolates. Applied and environmental Microbiology 67:1628-1635

21. Favaro L, Basaglia M, Casella S, Hue I, Dousset X, Franco BDGM, Todorov SD (2004) Bacteriocinogenic potential and safety evaluation of non-starter enterococcus faecium strains isolated from home made white brine cheese. Food Microbiol 38:228-239

22. Favaro L, Corich V, Giacomini A, Basaglia M, Casella S (2013) Grape marcs as unexplored source of new yeasts for future biotechnological applications. World J Microbiol Biotechnol 29:15511562

23. Smith PB, Hancock GA, Rhoden DL (1969) Improved medium for detecting deoxyribonuclease-producing bacteria. Appl Microbiol 18:991-993

24. Carneiro BM, Braga ACS, Batista MN, Rahal P, Favaro L, Penna ALB, Todorov SD (2014) Lactobacillus plantarum ST202Ch and Lactobacillus plantarum ST216Ch-what are the limitations for application? Journal of Nutritional Health and Food Engineering 1(2):00010

25. Vaucher RA, Teixeira ML, Brandelli A (2010) Investigation of the cytotoxicity of antimicrobial peptide $\mathrm{P} 40$ on eukaryotic cells. Curr Microbiol 60:1-5

26. Gomes BC, Esteves CT, Palazzo ICV, Darini ALC, Felis GE, Sechi LA, Franco BDGM, de Martinis ECP (2008) Prevalence and characterization of Enterococcus spp. isolated from Brazilian foods. Food Microbiol 25:668-675

27. Teuber M (1999) Spread of antibiotic resistance with food-borne pathogens. Cell Molecular Life Science 56:755-763

28. Todorov SD, Franco BDGM, Wiid IJ (2013) In vitro study of beneficial properties and safety of lactic acid bacteria isolated from Portuguese fermented meat products. Benefic Microbes 5:351-366

29. De Sousa CP (2003) Pathogenicity mechanisms of prokaryotic cells: an evolutionary view. Braz J Infect Dis 7:23-31

30. Franz CM, Muscholl-Silberhorn AB, Yousif NMK, Vancanneyt M, Swings J, Holzapfel WH (2001) Incidence of virulence factors and antibiotic resistance among enterococci isolated from food. Appl Environ Microbiol 67:4385-4389

31. Todorov S, Wachsman M, Ts I-I, Ivanova I (2014) Lactobacillus plantarum ST16Pa - are we ready to use it as bio-preservative culture? Bulgarian Journal of Agricultural Science 20:55-58

32. Holzapfel WH, Wood BJB (2014) Introduction to the LAB. Chapter 1. In: Holzapfel WH, Wood BJB (eds) Lactic acid bacteria-biodiversity and taxonomy. John Wiley \& Sons Ltd., Chichester, West Sussex, UK, pp 1-12

33. Franz CMAP, Stiles ME, Schleifer K-H, Holzapfel WH (2003) Enterococci in foods - a conundrum for food safety. Int J Food Microbiol 88:105-122

34. Hendrickx APA, Willems RJL, Bonten MJM, van Schaik W (2009) LPxTG surface proteins of enterococci. Trends Microbiol 17:423-430

35. Franz CMAP, Holzapfel WH (2004) The genus Enterococcus: biotechnological and safety issues. In: Salminen S, von Wright A, Ouwehand A (eds) The lactic acid bacteria: microbiology and functional aspects, 3rd edn. New York, Marcel Dekker, pp 199-247

36. Cook LC, Federle MJ (2014) Peptide pheromone signaling in Streptococcus and Enterococcus. FEMS Microbiol Rev 38: 473-492
37. Botes M, Van Reenen CA, Dicks LMT (2008) Evaluation of Enterococcus mundtii ST4SA and Lactobacillus plantarum 423 as probiotics by using a gastro-intestinal model with infant milk formulations as substrate. Int J Food Microbiol 128:362-370

38. Todorov SD, Dicks LMT (2008) Evaluation of lactic acid bacteria from kefir, molasses and olive brine as possible probiotics based on physiological properties. Ann Microbiol 58:661-670

39. Ammor MS, Flórez AB, Mayo B (2007) Antibiotic resistance in non-enterococcal lactic acid bacteria and bifidobacteria. Food Microbiol 24:559-570

40. Levy SB, Marshall B (2004) Antibacterial resistance worldwide: causes, challenges and responses. Nat Med 10:S122-S129

41. Salyers AA, Gupta A, Wang Y (2004) Human intestinal bacteria as reservoirs for antibiotic resistance genes. Trends Microbiol 12:412-416

42. Danielsen M, Wind A (2003) Susceptibility of Lactobacillus spp. to antimicrobial agents. Int J Food Microbiol 82:1-11

43. Elisha BG, Courvalin P (1995) Analysis of genes encoding d-alanine: d-alanine ligase-related enzymes in Leuconostoc mesenteroides and Lactobacillus spp. Gene 152:79-83

44. Salminen MK, Rautelin H, Tynkkynen S, Poussa T, Saxelin M, Valtonen V, Jarvinen A (2006) Lactobacillus bacteremia, species identification, and antimicrobial susceptibility of 85 blood isolates. Clin Infect Dis 42:35-44

45. Charteris WP, Kelly PM, Morelli L, Collins JK (1998) Development and application of an in vitro methodology to determine the transit tolerance of potentially probiotic Lactobacillus and Bifidobacterium species in theupper human gastrointestinal tract. Jornal of Applied Microbiolog 84:759-768

46. Coppola R, Succi M, Tremonte P, Reale A, Salzano G, Sorrentino Z (2005) Antibiotic susceptibility of Lactobacillus rhamnosus strains isolated from Parmegiano Reggiona cheese. Lait 85:193-204

47. Zhou JS, Pillidge CJ, Gopal PK, Gill HS (2005) Antibiotic susceptibility profiles of new probiotic Lactobacillus and Bifidobacterium strains. Int J Food Microbiol 98:211-217

48. Herreros MA, Sandoval H, González L, Castro JM, Fresno JM, Tornadijo ME (2005) Antimicrobial activity and antibiotic resistance of lactic acid bacteria isolated from armada cheese (a Spanish goats' milk cheese). Food Microbiol 22:455-459

49. Herrero M, Mayo B, Ganzales B, Suarez JE (1996) Evaluation of technologically important traits in lactic acid bacteria isolated from spontaneous fermentations. J Appl Bacteriol 81:565-570

50. Elkins CA, Mullis LB (2004) Bile-mediated aminoglycoside sensibility in Lactobacillus species likely results from increased membrane permeability attributable to cholic acid. Appl Environ Microbiol 70:7200-7209

51. Rojo-Bezares B, Sáenz Y, Poeta P, Zarazaga M, Ruiz-Larrea F, Torres C (2006) Assessment of antibiotic susceptibility within lactic acid bacteria strains isolated from wine. Int J Food Microbiol 111: 234-240

52. Ahn C, Collins-Thompson D, Duncan C, Stiles ME (1992) Mobilization and location of the genetic determinant of chloramphenicol resistance from Lactobacillus plantarum caTC2R. Plasmid 27:169-176

53. Huys G, D'Haene K, Swings J (2006) Genetic basis of tetracycline and minocycline resistance in potentially probiotic Lactobacillus plantarumstrain CCUG 43738. Antimicrob Agents Chemother 50:1550-1551

54. Salyers AA, Shoemaker NB (1996) Resistance gene transfer in anaerobes: new insights, new problems. Clin Infect Dis 23: S36-S43

55. dos Santos KMO, Vieira ADS, Buriti FCA, do Nascimento JCF, de Melo MES, Bruno LM, Borges MF, Rocha CRC, Lopes ACS, Franco BDGM, Todorov SD (2015) Artisanal Coalho cheeses as source of beneficil Lactobacillus plantarum and Lactobacillus rhamnosus strains. Dairy Science \& Technology 95:209-230 